\title{
A MULHER E A SOCIEDADE NO ROMANCE JUBIABÁ DE JORGE AMADO
}

\author{
M. C. SANTOS ${ }^{1 *}$ e I. F. CAVALCANTE ${ }^{2}$ \\ 'Universidade Federal da Paraíba (PROLING/UFPB) \\ ${ }^{2}$ Instituto Federal de Educação, Ciência e Tecnologia do Rio Grande de Norte (IFRN) \\ mairacordeiro@gmail.com*
}

Artigo submetido em setembro/2014 e aceito em novembro/2015

DOI: $10.15628 /$ holos.2015.2461

\section{RESUMO}

O presente trabalho versará sobre as várias representações da mulher no romance Jubiabá, de Jorge Amado (1976), cujo enredo se insere na sociedade do início do século $\mathrm{XX}$, na Bahia. Por meio de uma análise bibliográfica de autores como Perrot (1991; 2005), Buriti (2004), Stearn (2007), Carneiro (2000), Foucault (1986), dentre outros, busca-se entender como são representados os papéis sociais femininos inseridos dentro de uma sociedade marcadamente patriarcalista. A partir de diferentes personagens femininos, Jorge Amado discute sobre as representações da mulher branca de elite, da mulher negra, pobre, refletindo os ditames sociais em relação à maternidade, ao trabalho e ao desejo sexual. Com base na análise, pode-se perceber que o autor dá vez a uma classe menos favorecida, retratando os conflitos sociais inerentes às relações entre homens $e$ mulheres. Nesse espaço, a subversão às regras sociais tem importante destaque como reflexão do poder de liberdade da mulher.

PALAVRAS-CHAVE: Jubiabá, Jorge Amado, representações, gênero, literatura.

\section{WOMAN AND SOCIETY IN THE ROMANCE JUBIABÁ BY JORGE AMADO}

\begin{abstract}
This paper will focus on the various representations of women in Jubiabá, by Jorge Amado (1976), whose plot sets in the early twentieth century in Bahia society. Through a literature review of authors such as Perrot (1991, 2005), Buriti (2004), Stearn (2007), Carneiro (2000), Foucault (1986), among others, we seek to understand how female are represented in their social roles within a markedly patriarchal society. Throughout
\end{abstract}

KEYWORDS: Jubiabá; Jorge Amado; representation; gender; literature. 


\section{INTRODUÇÃO}

O presente trabalho versará sobre as várias representações da mulher no romance Jubiabá, de Jorge Amado (1976), cujo enredo se insere na sociedade do início do século XX, na Bahia.

O romance, publicado em 1935, quando Jorge Amado tinha apenas 23 anos, narra a história de Antônio Balduíno, órfão e morador do morro do Capa-Negro, que tinha como grande referência espiritual o centenário feiticeiro Jubiabá. Balduíno (ou Baldo, seu apelido) passa a infância nas ruas de Salvador, cometendo pequenos delitos, e apaixona-se por Lindinalva, uma mulher da elite que termina seus dias doente e prostituída. Durante sua vida, torna-se malandro, sambista, desordeiro, boxeador, encerrando prematuramente sua carreira após tomar uma surra no ringue por causa de uma noite de bebedeira. Depois do fato, Antônio Balduíno vai trabalhar nas plantações de fumo do Recôncavo Baiano, fugindo de lá para entrar em um circo ambulante. Intrigado com as contradições da vida, de volta a Salvador torna-se estivador e lidera uma greve por melhores condições de trabalho. Com variados temas, o autor discute a questão racial, a opressão política e as injustiças sociais, dando ênfase à classe menos favorecida e desprezada da sociedade.

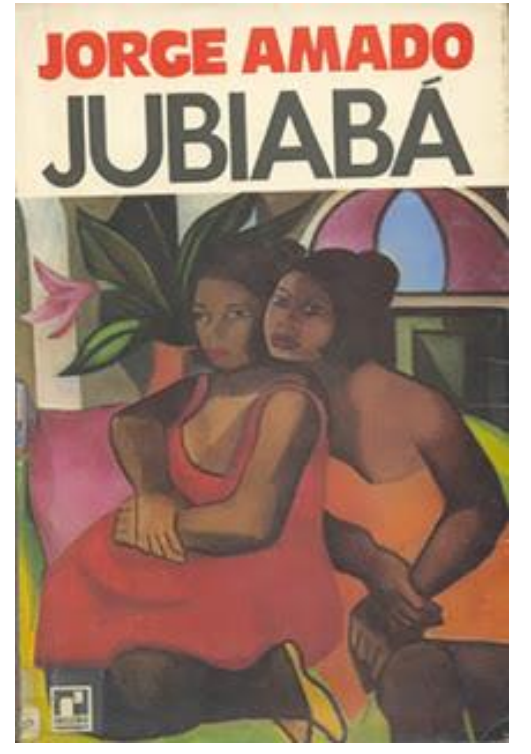

Figura 1. Capa do livro Jubiabá, de Jorge Amado (1935).

No contexto do romance, várias representações podem ser analisadas, como a noção da greve, do socialismo, da relação de trabalho entre pobres e ricos, a opressão do trabalhador e as condições e representações femininas. A fim de constituir um recorte para análise, busca-se compreender as representações femininas do romance e a sua relação com os discursos sobre a mulher que circulavam no início do século XX, no Brasil e, mais especificamente, no Nordeste.

A língua e os discursos devem ser entendidos como práticas sociais e culturais que são estabelecidos e constituídos pelas marcas sociais de cada comunidade. Esses discursos, ao mesmo tempo em que nascem da sociedade, também são responsáveis pelas mudanças e pelas coerções ligadas à memória que estabelecem as identidades nacionais, culturais, coletivas e individuais. 
Tomaremos como referência a noção de discurso empregada por Foucault, para entender de que forma os discursos que circulam na sociedade são representados no romance, ora confirmando-os, ora criticando-os:

[...] não mais tratar os discursos como conjunto de signos (elementos significantes que remetem a conteúdos ou a representações), mas como práticas que formam sistematicamente os objetos de que falam. Certamente os discursos são feitos de signos; mas o que fazem é mais que utilizar esses signos para designar coisas. É esse mais que os torna irredutíveis à língua e ao ato da fala. É esse mais que é preciso fazer aparecer e que é preciso descrever. (FOUCAULT, 1986, p.56)

Os discursos que circulavam na época manifestavam-se em diferentes suportes, como a oralidade, a literatura e os periódicos. Maria Odila Dias (2007) afirma que nos periódicos do início do século XX prevaleciam tendências normativas e conservadoras de modernização da mulher, determinando modos e papéis normativos da família conjugal burguesa. Nesse contexto, as brincadeiras populares sempre fizeram parte do cotidiano feminino nas cidades dessa época. Constantemente, brincadeiras relacionadas ao trabalho doméstico feminino, como o cuidado com as "filhas-bonecas", a prática do "cozinhado", a brincadeira de "casinha" com as colegas, pontuam os papéis sociais da formação da mulher como "dona do lar". Desde pequenas, elas são "treinadas" para o trabalho na casa, na cozinha e para a maternidade.

A representação do que deveria ser a nação estava pautada numa sociedade patriarcal que, segundo Buriti (2004), consistia numa trindade somática-física-moral que distinguia a mulher ideal (bela esposa, mãe dedicada, filha virtuosa, destituída de uma função produtiva fora do lar), sendo sinônimo de normalidade e vista como um corpo que tinha de ser higienizado, não só orgânica como moralmente, em prol da eugenia.

O romance Jubiabá traça perfis diferentes, mas convergentes das mulheres da época: embora vistas de diferentes ângulos, guardam em si semelhanças e diferenças que as identificam como mulheres: a maternidade, o romantismo, o amor, o afeto, a piedade, a alegria, a sensualidade e a docilidade. Ora são vistas como mães e protetoras, ora como objeto de desejo sexual pelo homem; ora como trabalhadoras, ora como dependentes do homem. São mulheres negras, brancas, pobres ou ricas.

Em uma sociedade que enfatiza a ideia de que "a mulher é o ser que espera, que a princípio se esquiva, ou resiste, que por fim se entrega, se abre, suporta a agressão; o homem é o ser que procura, que excita, que penetra, que agride" (PORTO-CARRERO, 2000, p. 162), Jorge Amado, no romance Jubiabá, denuncia a condição submissa em que a mulher se vê inserida, seja no trabalho, no seio familiar, no casamento ou na questão de sua sexualidade reprimida. Segundo Buriti (2004), a honra era vista como uma mercadoria usada para estabelecer relações de gênero centradas na hierarquização. Essa hierarquia de gênero é uma construção histórico-social baseada na anatomia dos corpos masculino e feminino e balizada na ciência médica. A família honrada era, no início do século XX, construída por uma mulher devota, ordeira, submissa e recatada, como também aponta Freyre (2000).

Essa concepção conduz a refletir sobre a relação entre literatura e sociedade e literatura e história. Segundo Antonio Candido (2006), Madame de Staël, na França, foi quem primeiro formulou 
e sistematizou a ideia de que a literatura é também um produto social, refletindo características de cada civilização em que ocorre:

Para o sociólogo moderno, ambas as tendências tiveram a virtude de mostrar que a arte é social nos dois sentidos: depende da ação de fatores do meio, que se exprimem na obra em graus diversos de sublimação; e produz sobre os indivíduos um efeito prático, modificando a sua conduta e concepção do mundo, ou reforçando neles o sentimento dos valores sociais. Isto decorre da própria natureza da obra e independe do grau de consciência que possam ter a respeito os artistas e os receptores de arte (CANDIDO, 2006, p. 29).

Nesse sentido, Walter Benjamin (1970) expressa que o senso prático é uma das particularidades de muitos narradores natos. Segundo o autor, a verdadeira natureza da narrativa tem sempre em si, às vezes de forma oculta, um valor utilitário. Essa utilidade pode representar um preceito moral, uma alusão prática, um provérbio ou um princípio de vida: de todo modo, o narrador proporciona conselhos. Esse narrador dissemina os discursos que circulam na sociedade, constituindo a identidade do povo. A identidade do povo brasileiro é, portanto, a síntese de todas as trocas culturais e discursivas com as tradições dos povos que passaram pelo país e que deixaram marcas no passado e no presente, criando uma nova comunidade discursiva, conforme afirma Hall (2006, p. 58), ao estabelecer que "os elementos que constituem uma cultura nacional como uma "comunidade imaginada" são as memórias do passado, o desejo por viver em conjunto, e a perpetuação da herança".

A mulher brasileira nasce tendo o espaço doméstico como função de trabalho que constrói a própria identidade feminina, refletindo suas escolhas, coerções, o percurso do discurso e das práticas sociais que atravessaram oceanos, mares, memórias e lembranças de milhares de mulheres que são representadas em várias escrituras, como a literatura.

Dessa forma, busca-se entender o papel da mulher no cenário social do início do século XX retratado no romance Jubiabá, discutindo as várias faces que a mulher assume em relação ao homem, à família e à própria sociedade do país.

A primeira parte do artigo busca analisar as representações da mulher em relação à questão socioeconômica, revelando as contradições entre pobres e ricas. O segundo tópico trata sobre as representações da mulher como protetora dos filhos e da família, reproduzindo o discurso corrente maternidade como função "natural" destinada às mulheres desde o nascimento. Por fim, a última parte discute sobre as representações da mulher em relação de dependência ao homem ou como objeto de desejo sexual e suas relações com os discursos sexistas e paternalistas da época.

\section{A MULHER E A QUESTÃO SOCIOECONÔMICA}

A abolição da escravatura, em 1888, não resolveu a questão racial no Brasil, ao contrário, reacendeu ainda mais a distinção entre negros e brancos, pobres e ricos. Entretanto, a faixa da pobreza envolveu um novo e velho personagem: o branco, conforme é expresso no próprio romance: "Negro ainda é escravo e branco também. Todo pobre ainda é escravo. Escravidão ainda não acabou..." (AMADO, 1976, p. 46). É nesse contexto que reside a grande distinção entre as mulheres ricas e as pobres. 
A mulher branca e rica no romance Jubiabá é descrita em sua beleza, de forma sutil, delicada, tal como a descrição de Lindinalva: "magríssima e sardenta, os cabelos pequenos e a boca pequena" (AMADO, 1976, p. 55). Em outras passagens, a mulher rica é vista como piedosa, carinhosa, como no episódio das esmolas ao pequeno Baldo e seus amigos, ou da mulher que implora ao seu marido aumento dos salários de seus funcionários para acabar com a fome das crianças: "As mulheres davam sempre, umas por piedade daqueles filhos da rua pensando nos filhos que estavam no aconchego das casas. (AMADO, 1976, p. 67), "sei é que tem crianças com fome. E eles ganham mesmo uma miséria. Você nunca me falou que sabia dessas coisas. E eu não sabia. Se eu soubesse..." (AMADO, 1976, p.322). Há entre essas mulheres uma compaixão de mãe e de mulher, que, independente da cor da pele ou do status social, as identificam apenas como mulheres e mães, sem qualquer distinção. Essa piedade também pode ser vista pelo tratamento destinado ao pequeno mendigo Felipe, o Belo: "Coitadinho... Tão pequenininho... Já sem mãe... Davam-Ihe largas esmolas. Três vezes foi convidado a morar em casas de senhoras ricas."(AMADO, 1976, p. 70).

Outra diferença que podemos apontar é a maneira como os próprios homens tratam as mulheres. Em relação às mulheres brancas há um tratamento delicado, amoroso e respeitoso, ligado ao ideal da época aos papéis sociais femininos relacionados ao trabalho doméstico. Esses aspectos são evidenciados por Perrot (2005) ao citar o elogio da dona-de-casa no discurso dos operários franceses no século XIX. Assim como os discursos dos operários franceses, essas ideias também se repetiam em vários outros espaços e sociedades durante essa época. Segundo eles, o destino da mulher deveria ser a família, a costura e os tecidos, enquanto ao homem caberia a madeira e os metais. Segundo o operário Proudhon "as funções da mulher inscrevem-se em sua conformação: uma vagina para receber, um ventre para carregar, seios para amamentar - como os pedaços dos melões - marcam seu destino, feito pelo homem e pelo filho. Nenhum lugar além do lar". (PERROT, 2005, p. 173). Os operários franceses do século XIX entendiam que o lugar da mulher era o trabalho doméstico no lar, a educação dos filhos, cuidados com as tarefas da casa, além de atividades como costurar e cozinhar. As mulheres não deveriam fazer qualquer trabalho contrário à delicadeza de seu sexo.

Podemos encontrar nas passagens em que o noivo de Lindinalva assim a trata "O que foi, querida? (...) Você é uma medrosa, querida" (AMADO, 1976, p. 85) ou na passagem em que Antônio Ruiz, o proprietário das Panificações Reunidas, discute com sua esposa Helena sobre a greve dos funcionários: "Está metida em política, filhinha? (...) Você não sabe nada dessas coisas, meu amor (AMADO, 1976, p. 321). "Não chore, Lena” (AMADO, 1976, p. 323). Nesses trechos encontram-se discursos ligados ao paternalismo, uma vez que, para Falci (2006), a mulher de elite, mesmo com certo grau de instrução, estava restrita à esfera do espaço privado, pois a ela não se destinava a esfera pública do mundo econômico, político, social e cultural. Segundo Perrot (1991), as mulheres estavam excluídas de qualquer participação nos negócios e na vida pública, reinando, portanto no espaço privado pelo sistema da etiqueta, das regras da "sociedade" e da "temporada". Em meados do século XIX, na imaginação inglesa, a casa realmente era o local das doçuras e delícias que, frequentemente, era registrado em cadernos de receitas culinárias, como forma de memórias para instruir as filhas. Esse local era percebido de formas diferentes pelos homens e pelas mulheres. Os homens podiam mesclar as preocupações, temores e profundas satisfações da vida pública aos encantos recolhidos do lar. Entre as mulheres raramente existia essa dualidade: possuíam apenas e exclusivamente o lar, quadro "natural" de sua feminilidade. 
As mulheres negras, ou melhor, as pobres, entretanto, têm um tratamento diferenciado em relação às ricas. A começar pela descrição das negras, muito mais hostil e, geralmente, com apelo sexual: "mulata gorda" (AMADO, 1976, p. 35), "Mas Antônio Balduíno, que estava acostumado com as negrinhas sujas do morro" (AMADO, 1976, p. 55), "Joana trazia os cabelos soltos, cabelos que ela espichava cuidadosamente, e os perfumava com um perfume que tonteava Antônio Balduíno. Ele enfiava o nariz chato no cangote dela, suspendia o cabelo e ficava aspirando aquele perfume. Ela dizia rindo: - Tira o focinho do meu pescoço... Ele ria também: - Que bodum gostoso... Jogava a negra de costas na cama. A voz dela vinha de longe: - Seu cão..." (AMADO, 1976, p. 92), "negras gordas vestidas com anáguas e camisas decotadas e colares no pescoço" (AMADO, 1976, p.103), "Uma mulata desdentada, bem clara, que nem valera a pena tanto esforço." (AMADO, 1976, p. 112). Além disso, constantemente as negras ("cabrochas") do romance costumavam passear com Baldo pelo areal a satisfazer-Ihe sua vontade sexual: “- Uma mulata, seu mano... - Aquela, Joaquim, tá ali, está comida... - Tá com um macho, Baldo (...) Mas como não havia mesmo outra mulher o jeito que tiveram foi levar a desdentada para o areal" (AMADO, 1976, p. 111/112).

Essa problemática é trabalhada por Maria Consuelo Cunha Campos $(2007$, p. 4) ao afirmar que:

Estereótipos literários como os da donzela casadoura branca, da mulata sensual e fogosa, da negra abnegada, submissa, máquina de trabalhar, corresponderam, respectivamente, à procriação, à questão patrimonial, familiar e sucessória e à exploração da mão-de-obra, numa sociedade patriarcal, sexista e racista e na qual a literatura frequentemente reforçou os lugares sociais assinalados ao gênero feminino e às chamadas raças.

Outras obras de Jorge Amado também apresentam essas representações ligadas às mulheres negras ou pobres: elas assumem a posição de subversão ao sistema privado doméstico de regras de etiqueta associados às mulheres de elite. Mais do que um preconceito velado, há a problematização da liberdade feminina, da rejeição à ordem imposta, à aceitação dos desejos da carne e do espírito.

No livro Mar morto (1936), mostra-se a dificuldade de adaptação da mulher ao meio em que vive, restando como opção ao falecimento do marido, o trabalho duro nas fábricas ou como lavadeira ou a prostituição. Em Dona Flor e seus dois maridos (1966), há a representação dupla da mulher: de dia, Dona Flor figura com seu marido letrado, educado, sério; à noite, rende-se a Vadinho, seu ex-marido morto, farrista, malandro, boêmio, infiel. Assim, Jorge Amado liga dois pontos opostos, ficando com a ambiguidade e o hibridismo como valores. Por fim, Tieta do Agreste (1977) apresenta a representação da mulher que é expulsa pelo pai por envolver-se sexualmente. De volta à cidade natal, dizendo-se rica e viúva, é logo aceita pela sociedade, até se descobrir que ela é dona de um bordel de luxo em São Paulo, retratando a hipocrisia social da época (BELLINI, s/d).

Algumas mulheres eram vistas como loucas, a exemplo de Augusta das Rendas que vivia assombrada pela alma de seu marido: "Ele me atrapalha que a senhora não imagina... Eu estou contando direito, ele começa a contar no meu ouvido depressa que faz medo. Quando eu ainda estou em três ele já está em vinte... Eu não posso com ele" (AMADO, 1976, p. 40/41) ou de Luísa, tia de Antônio Balduíno: "Estava magra e ossuda, os olhos pulados para fora do rosto que andava chupado. Beijou a mão da velha que o olhou com ar indiferente. - Titia, sou Balduíno... - Sabe de 
uma coisa: os moleques querem roubar o meu mingau. Você veio para roubar, não foi? - foi se enfurecendo" (AMADO, 1976, p. 59).

Apesar da diferença nítida entre as representações da mulher branca e da mulher negra encontrada no romance Jubiabá, vê-se que as descrições não são imutáveis. Basta analisar a jornada da personagem Lindinalva: de uma infância dócil de menina rica, que gostava de literatura e brincadeiras à espera de um noivo bonito e uma família dedicada, à tragédia da perda de sua mãe, de seu pai, de sua casa, de seu noivo, uma gravidez e a prostituição de seu corpo, decaindo até a sua morte:

Com a morte que se aproxima ela tornou a ser a mesma Lindinalva da Travessa Zumbi dos Palmares. Seu rosto está sereno e belo. Seu rosto sardento, rosto de santa. As mãos que tocavam piano e machucavam as rosas são as mesmas. Nada resta da Lindinalva da Pensão Monte Carlo, da Linda da Rua de Baixo, da Sardenta da Ladeira de Tabuão. Ela agora é novamente a filha do Comendador que morava na casa mais bonita da Travessa Zumbi dos Palmares e esperava um noivo na Nau Catarineta. Mas ela se move e aparece outra Lindinalva. Esta Antônio Balduíno não conheceu. Mas Amélia sabe qual é. É a noiva de Gustavo, é a amante de Gustavo, é a mãe de Gustavinho. Um rosto risonho de senhora jovem.[...]. (AMADO, 1976, p. 284).

Em outras obras, Jorge Amado também enfatiza a trajetória trágica das mulheres brancas de elite. Em Terras do sem-fim (1943), há o conflito da jovem de elite Ester, que figura entre o ódio ao grosseiro marido e a paixão por Virgílio, que se resolve apenas no plano da morte, ao infringir as leis de ordem moral ligadas à sua condição social. A obra Gabriela, cravo e canela (1962) também apresenta essa relação entre mulheres ricas e pobres. Malvina, personagem de classe alta, enfrenta seus pais e, sem aceitar o casamento, foge para estudar em São Paulo, rompendo com os padrões sociais esperados e desejados pela sua família. No mesmo romance, Gabriela representa a pobre retirante, associada à sexualidade e sensualidade. Ao trair seu marido Nacib, de quem fora amante, Gabriela arrepende-se do casamento, mas não da traição (BELLINI, s/d).

Parece que Jorge Amado procura distorcer e problematizar as representações de gênero da época que Perrot (1991) expõe a partir da história do novo ideal doméstico: pretendem-se moralizar com as virtudes da boa dona de casa as mulheres das classes operárias. As da pequena nobreza se convertem às práticas de uma sociabilidade mais íntima e transformam seus castelos em interiores domésticos. As atividades domésticas, cada vez mais reservadas às mulheres da burguesia e das classes superiores, eram consideradas como as mais adequadas ao desenvolvimento das práticas cristãs.

Com isso, nota-se que a grande diferença entre as mulheres não reside na cor de sua pele, mas na questão econômico-social em que estão inseridas. A mulher rica, na visão da escritora Júlia Lopes de Almeida, desde o dia do casamento, passa a ser adorno de luxo do marido, rodeando-Ihe de afeto, de dignidade, purificando o nome dele, não maculando o seu sobrenome com comportamento desregrado e, consequentemente, não denegrindo a nação, pois "é a nós, como mães, que a Pátria suplica bons cidadãos; é de nós, quando esposas, que a sociedade exige o maior exemplo de dignidade e moral" (ALMEIDA, apud BURITI, 2004). As mulheres pobres ainda são tidas como mão de obra à satisfação do conforto dos ricos ou nas fábricas, perdendo sua beleza, saúde e alegria a troco de migalhas. Entretanto, no romance essas representações se cruzam, uma vez que 
a doce e rica Lindinalva sucumbe às tragédias de sua família e representa a subversão à ordem imposta.

\section{A MULHER COMO PROTETORA DOS FILHOS E DA FAMÍLIA}

Apesar da divergência acima apontada que distingue as mulheres de acordo com a classe social e a raça a qual pertencem, existe um traço semelhante em todas elas, presente em todo o romance Jubiabá: a maternidade e proteção à família.

Assim, vê-se que a maternidade ultrapassa todas as barreiras e todas as divergências entre as mulheres, aproximando-as do que parece ser uma qualidade "natural" imposta pela sociedade. A preparação para esse atributo feminino da maternidade e do cuidado com a casa começa desde cedo. Cabe às mães "preparar" suas filhas para o casamento e a consequente administração do novo lar. O exercício da maternidade é cultivado pelas meninas por meio das brincadeiras e também pelo cuidado com os irmãos pequenos. Não raras vezes, muitas meninas tiveram que assumir o cuidado da casa e dos irmãos para ajudar sua mãe. As filhas que não casam ficam destinadas ao cuidado do lar e dos pais quando a mãe não mais puder exercer tais funções.

Iranilson Buriti (2004, p. 5) afirma que "as reportagens do Diário de Pernambuco, na década de 20 do século passado, deixavam claro que uma das preocupações da Igreja, do Estado e da própria medicina era controlar os filhos criticando muitas atitudes individuais de liberdade excessiva".

Podem-se verificar exemplos do afeto materno por todo o romance. Primeiramente com Luísa que, além de tia, foi pai e mãe de Antônio Balduíno durante toda sua infância no morro do Capa-Negro: "Sua tia Luísa fora-Ihe pai e mãe" (AMADO, 1976, p.21).

Em outras passagens, a mãe, mesmo quando ausente por qualquer motivo, sempre aparece no momento em que o filho mais precisa, revelando seu grande amor e afeto, nas ocasiões de dor ou sofrimento, como no caso da mãe que aparece para cuidar do filho doente Rozendo: "- Eu vou morrer... Vão chamar Mamãe... Mamãe... (...) pelo meio da tarde, Viriato, o anão, trouxe uma preta gorda. Rozendo delirava e não a reconheceu. Ela se abraçou com ele e o levou" (AMADO, 1976, p. 76/77), ou quando a mãe de Felipe, o Belo, aparece em seu enterro: "O corpo foi levado para o necrotério. Veio uma mulher pintada e velhusca que dizia entre lágrimas: - Mon chéri... Mon chéri... E beijava o rosto de Felipe, o Belo. Mas ele não via mais nada e não sabia que era sua mãe que estava ali" (AMADO, 1976, p.87).

O papel da mãe como protetora é tão visível na mente das personagens e da própria sociedade que Viriato, o Anão, se questiona: "- E se eu ficar doente? Eu não tenho mãe, nem pai, nem ninguém..." (AMADO, 1976, p.77).

A maternidade também é verificada em outra personagem corriqueira nas famílias: a avó. $\mathrm{Na}$ ocasião, o personagem Gordo adota uma velha que andava na rua como sendo sua avó, para suprir a carência do amor materno em sua vida, dando-lhe carinho e atenção: "Mas fazia como se ela fosse sua avó, levando-Ihe comida, conversando horas e horas com ela, se recolhendo cedo para que a velha não ficasse sozinha" (AMADO, 1976, p.109). 
A necessidade e proteção dos filhos são muito exploradas no romance, fazendo com que as mães doem seu alimento, ou os busquem unicamente para satisfazer a necessidade fisiológica dos filhos: "- Não tem pão por causa do leite para a criança" (AMADO, 1976, p. 113), "a comida é pouca para tantas bocas e os garotos reclamam mais" (AMADO, 1976, p. 160), "Lindinalva tem um filho e gostaria de viver para ele. Mas da Ladeira do Tabuão as mulheres só saem para o cemitério" (AMADO, 1976, p. 280), "Os filhos eram três, corriam pela porta, brincando de picula. Que iria dar às crianças para comer? (...) Que faria das crianças? Mandaria pedir mais comida?" (AMADO, 1976, p. 318).

Quando não conseguem o alimento, as mulheres se veem obrigadas a ingressar no trabalho das fábricas dos novos burgueses, perdendo sua saúde e beleza a troco de um ínfimo salário e jornadas extenuantes de trabalho: "Nas fábricas de charuto não havia trabalho. Ali quase só mulheres pálidas e macilentas, mulheres de olhos compridos, fabricavam charutos caros para fins de banquetes ministeriais" (AMADO, 1976, p. 154), "- A vida aqui é difícil? (...) - E as patroas ganham bem? - Nada... Que bem... E ainda tem as multas, tem as faltas por causa das crianças, doenças, e ficam logo velhas, acabadas" (AMADO, 1976, p.159).

O trabalho aglutina esses movimentos de equilíbrio e aponta novas conformações da vida social feminina, com a presença da dupla jornada de trabalho, no meio público e privado. A partir da imaginação simbólica, as mulheres procuram amenizar os conflitos existentes e restabelecer o equilíbrio que as possibilitem ser mulheres, esposas, mães, filhas, netas, etc. Nesse sentido, Durand (1993, p. 100) afirma que "o símbolo é concebido como uma síntese equilibrante através da qual a alma individual se une à psique da espécie e apresenta soluções tranquilizadoras para os problemas que a inteligência da espécie coloca". Os segredos, as experiências e as memórias em torno do ambiente doméstico desempenham o papel de conceder às mulheres o restabelecimento do equilíbrio, quanto à sua natureza biológica, que parece direcionada para o instinto maternal e familiar, quanto ao seu estado psíquico, permitindo a coexistência das suas atividades como mulher, mãe, dona-de-casa e trabalhadora, e quanto à sua posição na sociedade, historicamente relacionada com o casamento e com a maternidade.

Assim, a mulher é "obrigada" pela sociedade e pelo próprio instinto a se vincular à família e à maternidade, passando pela ideia de monogamia que é tida como "a grande lei da perpetuidade do vínculo conjugal, tão imperiosamente exigida pelo bem da prole (...), postulado psicológico da felicidade individual dos cônjuges (...). Ser monogâmico é gerar o alimento para a floração magnífica de um jardim chamado família, cuidado pelo estrume da afeição, pelo fertilizante do amor, pela água da completa doação" (FRANCA, Padre L. apud BURITI, 2004).

Autoras femininas do final do século XIX e início do século XX também ressoam esses discursos acerca das posições femininas no cenário social. Júlia Valentina da Silveira Lopes de Almeida, escritora carioca, publicou em 1896, O livro das noivas, em que ensinava às jovens donzelas casadoiras ou recém-casadas as artes para cuidarem do marido. No livro, há diversas dicas de como lidar com a casa ao lado de receitas, como a do Club sandwich e o Pudding dos recém-casados. Júlia Lopes discutiu muitos assuntos e fez campanhas em defesa da mulher e de suas condições. Como voz elitizada do mundo feminino, defendeu o cotidiano da mulher, a prática da cozinha e da comida, enquadrando a mulher como "bastião da casa", "rainha do lar" ou "defensora do lar". Eulalia Vaz, professora da Escola Profissional de São Paulo, publicou em 1912, o livro "Sciencia no lar moderno", 
manual para donas-de-casa em que se ensinavam normas de higiene, como preservar latas de banha, escolher bem os miolos e lavar e esfregar bem a cozinha com areia fina de beira de rio.

\section{MULHER X HOMEM: RELAÇÃO DE DEPENDÊNCIA E DESEJO SEXUAL}

Outra semelhança encontrada entre as mulheres é a sua relação com o homem. No início do século $\mathrm{XX}$, a mulher era vista como um ser submisso à figura masculina, fruto da tradição paternalista ocidental. Segundo Stearn (2007), culturalmente, os sistemas patriarcais realçavam a inferioridade das mulheres e sua fragilidade. Fixavam atenção aos deveres domésticos e algumas vezes limitavam os direitos das mulheres a viverem no espaço público. A abrangência do patriarcalismo foi intensa e vasta e, por isso:

[...] uma mulher desonrada 'ofendia': a) à autoridade paterna; b) às formas estabelecidas pelo discurso católico quanto ao casamento e ao batizado; c) à reputação pública da família; d) a sua própria integridade moral; e) ao patrimônio familiar; f) ao estado. Pudor e fidelidade eram requisitos exigidos de uma mulher honrada. Ao contrário, estava 'solta na buraqueira' (BUTITI, 2004, p. 3).

Em algumas passagens do romance Jubiabá é refletida a hierarquia de gênero, relacionandose a imagem da mulher à do homem, quando as mulheres são enganadas ou desprezadas por eles: "Prometeu um mundão de coisas... Eu feito besta acreditei nele... Levamos por aí uma vida ordinária... Me encheu desse jeito... Tive de trabalhar e amarelei, perdi a cor, ele foi embora com uma cabrocha vagabunda que vivia abrindo os dentes para ele..." (AMADO, 1976, p. 32); ou quando desejam um noivo para casar: "A senhora vai ganhar um noivo bonito que vem num navio..." (AMADO, 1976, p. 68), "Não tinha uma mulher gritando pelo noivo?” (AMADO, 1976, p. 150), "A Nau Catarineta podia lhe trazer um noivo, quem sabe. Uma vez um menino que pedia esmolas dissera que seu noivo viria no bojo de um navio cortando os mares" (AMADO, 1976, p. 269).

Porém, o tema mais recorrente no romance é a mulher como objeto de desejo sexual do homem, apesar de o discurso social da época "expressar os códigos de controle social impostos à mulher, caracterizadores da normatização de sua sexualidade. O hímen era entendido como um código de honra a ser utilizado numa aliança - o casamento - feita com derramamento de sangue" (DIÁRIO DE PERNAMBUCO apud BURITI, 2004, p. 3).

Não raras vezes há imagens sexuais no romance sempre com objetivo de satisfazer a libido masculina: "Ele sabia conversar com elas e terminava sempre com levá-las para o areal, onde se enroscavam, sem sentir a areia que entrava pela carapinha. Ele as amava e não as via mais" (AMADO, 1976, p. 98). "“Ficaram passeando no Campo Grande, ele sem ter conversa porque ela era donzela e donzelas não interessam ao negro" (AMADO, 1976, p. 99), "Maria dos Reis escondeu Antonio Balduíno no seu próprio quarto, sem que a mãe, que dormia, visse. E quando pela madrugada o negro saiu, o corpo da dos Reis ainda era macio e quente, mas não era mais virgem" (AMADO, 1976, p. 120), "Mestre Manuel (...) foi com a mulher para o fundo do saveiro. Estão escondidos atrás da camarinha. Mas se ouvem os ruídos dos corpos no amor. Vêm gemidos em voz baixa, súplicas de beijos" (AMADO, 1976, p. 153), "- Aquela é a única que é comível..." (AMADO, 1976, p. 157), "- Você ri porque é casado... Tem mulher... Pode ser um couro mas é mulher e eu que já faz quase um ano que não vejo uma égua na cama..." (AMADO, 1976, p. 167). 
Segundo Carneiro (2000), a história da sexualidade ou dos comportamentos sexuais da humanidade é bem mais ampla do que a "história do amor", como modelo medieval e como construção cultural. Para a Igreja Católica, o amor é a constituição da vida por Deus. O amor da "carne", entretanto, é considerado "o mal, o vício, a paixão, o deleite, a concupiscência, a lascívia, a devassidão, a libertinagem, a dissolução, a depravação, a luxúria" (CARNEIRO, 2000, p. 8). Umas das fontes para constituir a trajetória da história do amor, inclusive, é a literatura, desde Homero até a modernidade, que fez da vida sexual um tema de destaque. Segundo o autor:

Os textos moralistas trazem, portanto, mais do que uma teorização, uma profissão de fé e uma confissão pública de uma vida que se propõe exemplar, uma política sexual e uma micropolítica de regulação e controle dos corpos, praticadas em dimensões híbridas e conexas do Estado, da Medicina e da Igreja. (CARNEIRO, 2000, P. 13).

O sexo é um tema tão recorrente que os homens chegam a fantasiar, a sonhar e até cometer crimes a fim de satisfazer suas necessidades sexuais: "As mulheres riem e todas o querem, mas ele está com a atriz que conheceu num teatro e que se dependura no braço dele de uma maneira que roça os seios no seu peito. (...) Mas, agora, ela está novamente no quadro, com o leque em cima do sexo, porque o jirau está balançando muito e Antônio Balduíno se moveu na sua cama de tábua no outro lado da sala" (AMADO, 1976, p. 170), "Antônio Balduíno fica imaginando como serão os seios de Arminda fora do vestido. Olhe que bicos grandes que eles têm. Chegam a formar uma bola no vestido. (...) Os seus seios serão duros e carnudos" (AMADO, 1976, p. 175), "Matou Zequinha, matou... Mas foi porque ele estava andando com uma menina de 12 anos... Uma menina, não era uma mulher feita... Uma menina, tão menina que a mãe quando morreu tomava conta dela..." (AMADO, 1976, p. 187).

Apesar de toda a sociedade tratar a mulher como um ser dependente, devendo manter-se intacta sexualmente, a questão da prostituição (como profissão) é um tema recorrente não apenas no romance Jubiabá, ou no inicio do século XX, mas em toda a história da humanidade.

Na maioria dos casos de prostituição narrados no romance, as mulheres levam uma vida muito difícil e triste, obrigando-se a vender seu corpo para, muitas vezes, manter seus filhos: "Chamava-se Felipe e foi apelidado de Felipe, o Belo. Não possuía nenhuma história a não ser a que a mãe fazia a vida nos bordéis da Rua de Baixo, francesa velha que um dia se apaixonara por um estudante" (AMADO, 1976, p. 68), “- Eu já tive até família... Parece?... Nem parece... Mas eu tive duas filhas que até botei no colégio... Um branco botou feitiço numa, carregou com ela não sei pra onde... A outra vive aí em Cachoeira, parecendo uma doida com os cabelos cortados, fazendo a vida" (AMADO, 1976, p. 197), “-Eu sou mulher da vida... Nunca fui casada... - Pensei... - O que é que ele podia fazer? Ele não tinha dinheiro mesmo... Como é que ele ia criar o filho... Fugiu de noite como um ladrão... Deixou as coisas todas lá em casa... E eu sei que ele gostava de mim..." (AMADO, 1976, p. 199), "O negro apertou a cintura de Rosenda Rosedá. Mas ela corre para a barraca. Agora ela está no cabaré triste da cidade" (AMADO, 1976, p. 230), "Ela veio vender sua virgindade esta noite para comprar remédios. Pois a mãe não está doente, quase à morte e sem médico, sem um único vidro de remédio? "- Nós tamos mortas e não sabemos. A vida acabou para a gente. (...) Mulher-dama é escarradeira de todo mundo..." (AMADO, 1976, p. 273/274). 
Esses trechos denotam, como outros temas abordados no romance discutidos anteriormente, a subversão aos ditames sociais. Na verdade, Jorge Amado procura representar uma visão da sociedade desprezada pelas elites. A problematização das relações sociais na camada baixa da sociedade, com representantes negros e pobres, dá ênfase aos aspectos de relacionamento vivenciados por esses personagens, que representam tantos homens e mulheres reais. Essas questões aparecem como um "grito" ou crítica aos padrões sociais ditados na sociedade patriarcal, que menospreza as mulheres, em diferentes representações.

Peculiar é a trajetória de Lindinalva, menina rica da sociedade que, após sucessivas tragédias em sua família, vê-se obrigada a prostituir-se para manter seu filho Gustavinho, fruto de um amor extra-matrimonial com Gustavo: "Lindinalva naquela noite fez a sua estreia na pensão Monte Carlo com um vestido de baile bem decotado (...) Ela tinha um tipo esguio de virgem que devia agradar aos velhos. E que explorasse o mais que pudesse. Era a vida..." (AMADO, 1976, p. 273), "Cedo ficou velha para as pensões caras. Eunice já foi para a Rua de Baixo onde mulheres cobram cinco mil-réis. Hoje é Lindinalva que irá. (...) Agora sabe palavras feias em francês e toda a gíria das mulheres da vida. Mas o menino diz 'mamãe, mamãe', e ela se sente pura como uma virgem." (AMADO, 1976, p. 275), "Lindinalva desceu várias ladeiras. Foi ficar bem perto da cidade baixa, foi ficar na Ladeira do Tabuão. Da Ladeira do Tabuão as mulheres só saíam ou para o hospital ou para o necrotério." (AMADO, 1976, p. 276/279), "Ela está dizendo que quer o filho, que o tragam que ela vai morrer. Amélia volta chorando. Antônio Balduíno pergunta: - E o doutor? - Não pôde fazer mais nada... Disse que agora é esperar a morte.” (AMADO, 1976, p. 284), “- Ela era virgem, gente... Eu juro que era... Ninguém teve ela... Ela não foi de ninguém... Vivia disso mas não se dava... só eu que tive ela... Só eu, gente... Quando eu andava com uma mulher tava com a cabeça nela... Quero um caixão branco para ela..." (AMADO, 1976, p.286).

A trajetória de Lindinalva reacende a discussão das representações sociais vividas na sociedade patriarcal, sobretudo no início do século XX. As mulheres de elite tinham um destino guardado: raramente aprenderam a ler, no entanto, aprendiam a arte de bordar em branco, o crochê, o matiz, a costura, a música, a culinária. A história de Lindinalva revela as contradições da sociedade, as hipocrisias sociais. Uma vez que teve um filho fora do matrimônio, ela deve ser "destituída" de seus padrões, pois infringiu uma regra moral e social.

Não só em Jubiabá, mas na maioria de seus romances, Jorge Amado centra suas narrativas na condição feminina. Focalizando-as à margem da vida social, o autor atribui a essas mulheres a força para se contrapor à ordem estabelecida, criticando, dessa forma, a sociedade hipócrita e patriarcal da época. Ao subverter a ordem, elas inauguram um novo momento de celebração da vida e da liberdade, do corpo e da alma.

\section{CONCLUSÃO}

Apesar de todas as características e representações apontadas neste trabalho (que não excluem outras eventualmente encontradas), sobretudo sobre a submissão, dependência e preconceito sofridos pela mulher no início do século XX, na Bahia, verifica-se, no romance Jubiabá, que há um diálogo da mulher com o homem, numa tentativa de relativizar os padrões impostos. 
O que há nesse romance são várias representações femininas em torno das questões sociais vividas na época. Jorge Amado procura representar os discursos e as relações sociais entre homens e mulheres e, mais do que isso, problematizar as regras sociais impostas, dando vez à mulher de classe social pobre, mostrando-a em várias de suas faces: como mulher, como mãe, como detentora de desejo sexual e como portadora de liberdade de escolha. Essa análise nos faz refletir sobre as posições que a mulher assume na vida cotidiana, ao longo dos anos, e sobre as imposições de que é vítima constantemente. Subverter a ordem imposta demonstra liberdade e, acima de tudo, um desejo de mudança social.

\section{REFERÊNCIAS}

1. ALMEIDA, Júlia Valentina da Silveira Lopes de. O livro das noivas. São Paulo: Francisco Alves, 1986.

2. AMADO, Jorge. Jubiabá: romance; ilustrações de Carybé. 32. ed. Rio de Janeiro, Record, 1976.

3. BELLINE, Ana Helena Cizotto. Representações do feminino em Jorge Amado. In: GOLDSTEIN, Norma Seltzer (org.). Cadernos de leituras: a literatura de Jorge Amado: orientações para o trabalho em sala de aula. Companhia das letras, s-d. Disponível em: $<w w w . j o r g e a m a d o . c o m . b r>$. Acesso em: 10.09.14.

4. BENJAMIN, Walter. O narrador: considerações sobre a obra de Nikolai Leskov. In: Magia e técnica, arte e política. Obras Escolhidas 1. São Paulo: Brasiliense, 1986.

5. BURITI, Iranilson. Espaços de Eva: A mulher, a honra e a modernidade no recife dos anos 20 (século XX). Revista História Hoje. São Paulo, no 5, 2004. ISSN 1806.3993. Disponível em: <http://www.anpuh.uepg.br/historia-hoje/vol2n5/iranilson.htm>. Acesso em: 01 out. 2007.

6. CAMPOS, Maria Consuelo Cunha. Representações da mulher negra na literatura brasileira. Anais do XII Seminário Nacional Mulher e Literatura. UESC. 2007. Disponível em: < http://www.uesc.br/seminariomulher/anais/PDF/Mesas/Maria\%20 Consuelo \%20Cunha\%20 Campos.pdf>. Acesso em: 16.09.14.

7. CANDIDO, Antonio. Literatura e sociedade. 9. Ed. Rio de Janeiro: Ouro sobre Azul, 2006.

8. CARNEIRO, Henrique. A igreja, a medicina e o amor: práticas moralistas da época moderna em Portugal e no Brasil. São Paulo: Xamã, 2000.

9. DIAS, Maria Odila Leite da Silva (coord.). Modos de ser femininos, relações de gênero e sociabilidades no Brasil. Disponível em: <http://www.fazendogenero7.uf sc.br/st_12.html> . Acesso em: 01 out. 2007.

10. DURAND, Gilbert. A imaginação simbólica. Lisboa: edições 70, 1993.

11. FALCl, Miridan Konx. Mulheres do sertão nordestino. In: PRIORE, Mary del (org.). História das mulheres no Brasil. 8 ed. São Paulo: Contexto, 2006.

12. FIGURA 1. Capa do livro Jubiabá, de Jorge Amado (1935). Fonte: http://livrespensantes.blog spot.com.br/2012/01/os-cem-anos-de-jorge-amado.html

13. FOUCAULT, M. A Arqueologia do saber. Rio de Janeiro: Forense, 1986.

14. FREYRE, Gilberto. Casa Grande \& Senzala. 40 ed., São Paulo: Record, 2000. 
15. HALL, Stuart. A identidade cultural na pós-modernidade. Trad. Tomaz Tadeu da Silva. 11. ed. Rio de Janeiro: DP\&A, 2006.

16. IMAGEM 1. Capa do livro Jubiabá, de Jorge Amado. 1935. Disponível em: <http://livrespen santes.blogspot.com.br/2012/01/os-cem-anos-de-jorge-amado.html>. Acesso em: 15.09.14.

17. PERROT, Michelle (org.). As mulheres ou os silêncios da história. Trad. Viviane Ribeiro. Bauru, SP: EDUSC, 2005.

18. PERROT, Michelle (org.). História da vida privada, 4: da Revolução Francesa à Primeira Guerra. Tradução: Denise Bottman e Bernardo Joffily. São Paulo: Companhia das Letras, 1991.

19. PORTO-CARRERO, J. P. apud CAULFIELD, S. Em defesa da honra: moralidade, modernização e nação no Rio de Janeiro (1918-1940). Campinas: Unicamp, 2000.

20. STEARNS, Peter N. História das relações de gênero. São Paulo: Contexto, 2007.

21. VAZ, Eulalia. Sciencia no lar moderno. 1912. Disponível em: <http://www. brasiliana.usp.br/bbd/handle/1918/01832400\#page/1/mode/1up>. Acesso em: 13 ag. 2011. 